\title{
Value Creation of Thai Herbs in Natural and Herb Products Industry Leading to Patent Protection
}

\author{
Korntana Yaowarat *, Thanin Silpcharu and Punsavadee Pongsiri
}

Faculty of Business Administration, King Mongkut's University of Technology North Bangkok, 1518 Pracharat 1 Road,Wongsawang, Bangsue, Bangkok 10800, Thailand; tanin@fbakm.com punsavadee.p@fba.kmutnb.ac.th

* Correspondence: s5714011950097@email.kmutnb.ac.th; Tel.: +66-992-538-784

\begin{abstract}
The main obstacle affecting the natural and herbal products industry is the infringement of trade patents. This resulted in losing the opportunity to compete with others in this business. Creating additional value to this business is, therefore, a way of leading to patent protection for entrepreneurs. This study was conducted to develop the structural equation modeling of guidelines for creating additional value for Thai herbs to support trade patent. The study comprises a mixed method with three parts. In the first part, data comes from interviews with selected nine specialists. The second part was supported by interviews to create the questionnaire and distributed it to five hundred entrepreneurs and then take the data analysis using a structural equation model. The third part discusses the focus on developing the model by seven experts. The analysis of the developed model passed the criteria for evaluating consistency and empirical data. All hypotheses proposed in this study were supported, the findings revealed that all factors had a direct effect at a statistically significant level of 0.001 . Furthermore, this investigation allows knowing the Brand Identity factor were practically important for creating value of Thai herbs leading to patent protection.
\end{abstract}

Keywords: Value creation; Thai herbs; Industry; Patent; Structural equation model

\section{Introduction}

Herbs are natural resources that humans have been used to treat diseases and illnesses for a long time since the primitive era. This herbal remedy has been passed down from generation to generation. It may be in the form of a textbook of traditional medicine or from one generation to the next. Until it became an herbal medicine used to treat various diseases and herbal medicine has emerged in many countries. This made the World Health Organization realize the importance of using herbs to develop into modern medicine and include them as part of the treatment of disease. Especially in Africa where more than 80 percent of the population has traditional herbal remedies [1] The demand for herbs in the world market tends to increase every year. The World Health Organization estimates that the global market for herbs as a component of medicines, food, and other products will increase by at least 20 percent per year. The market for herbal products in the world market in 2011 was valued at up to 60 billion US dollars, especially herbs in the group of beauty products, dietary supplements, herbal drinks, and herbal medicines. The major herbal products markets are in Europe and North America. China and India dominate the herbal product manufacturing market [2-3].

The natural products from herbs consumption trend tend to increase continuously. As a result, many consumers have turned to use herbal medicines instead of synthetic chemical drugs that may cause side effects [4]. Therefore, considering the potential of Thailand, which is rich in natural resources with high biodiversity. It is therefore a good opportunity for Thailand to use these advantages as a basis to drive the country's herbal innovation business. In the past, consumers in Thailand have given more importance to health care as well as other civilized countries, and consumers in these groups tend to increase continuously, especially focusing on body maintenance, beauty, as well as reducing 
the risk of various diseases. From the data of the Thai herbal and herbal extracts export market in 2018, the value was higher than 7,600 million baht. It can be seen that the market has a continuously growing trend. [5].

There are many types of plants, especially herbs, so they are used in a variety of ways and can be seen in everyday life. Both from being sold in various fresh markets as well as being used for cooking food in restaurants and households. Therefore, it is not unusual to be seen as a worthless item. In addition, the geographical advantage is another factor that contributes to the good reproduction in tropical climates, creating unique and endemic biodiversity, allowing crops to rotate throughout the year. The use of herbs in addition to being used in cooking. It is also used to treat common diseases inherited from the knowledge of traditional wisdom such as ground medicine, fermented medicine, and rubbing medicine until it has evolved into a bolus, powder, and capsule. The use of herbs and traditional medicine knowledge is gaining a lot of attention in the global market and is likely to continue to gain more attention [6-7]. Therefore, the researcher is interested in studying the ways to create added value of herbs in the natural and herbal products industry leading to trade patents by studying the value-added of herbs in each relevant aspect to create a competitive potential for the business as well as to improve and develop the declining traditional herbal business group for sustainable growth.

\section{Literature Review and Theoretical Framework}

\subsection{Brand Identity}

As the business environment changes rapidly, the brand is an important tool for consumers to remain trusted in meeting their needs. The function of the brand is to meet the needs of consumers by creating memorable and valuable experiences through products and services delivered to the target group and then communicate through channels that influence consumer perception [8]. This is considered a key strategic point of the brand. Therefore, entrepreneurs should find a key strategic point to create an experience that conquers consumer's hearts and attaches great importance to offering products and services based on promise to customers [9].

Branding is a must for entrepreneurs. It must be differentiated and unique to be remembered and lead to repeat purchases until brand loyalty. Once a unique brand is created and developed towards acceptance, it is best to communicate that brand identity to internal personnel first to create an understanding and unity of the organization in presenting the brand to the target consumer. The brand identity is then presented to the target customers with a marketing communication strategy to reach the target customers clearly [10-11].

Therefore, brand identity influences marketing strategies in which the created brand identity must communicate to the target consumers to create awareness of the brand's value and influence research and development. In other words, it must be able to make a difference. In particular, the difference in perception between the brand and the competitors [12].

\subsection{Marketing Strategy}

Marketing strategy formulation is an important factor for industrial business. It will be something that can be used to communicate within the organization for a common operating direction and business goals. It also determines the future of the business in which direction it will proceed. Therefore, formulating a marketing strategy must be concise, able to communicate at all levels in the organization, and create a common feeling. It can also be linked to future marketing plans to allocate organizational resources efficiently [13]. Strategy formulation starts from determining the direction of the market to 1) employees in all departments of the organization are involved in activities aimed at improving and understanding the current and future needs of customers, including factors affecting people in the organization 2) exchange of knowledge among each department of the organization; and 3) various departments within the organization 
participate in defining and designing various activities to meet the needs of customers. Then set up marketing strategies, publish the information to create acceptance and response to information at the organizational level, thus formulating marketing strategies will be successful [14].

When the organization has a marketing strategy, it is necessary to communicate to let the market know what the organization provides to consumers to perceive the value of products and services. It is a goal of informing, persuading, and reminding consumers both directly and indirectly. Therefore, marketing communications bring the organization's brand to life, able to communicate and build relationships with its target consumers over time [15-16].

\subsection{Research and Development}

Research and development are a tool to stimulate and encourage innovation by relying on the advancement of various technologies to create products and services to meet the needs of customers. [17]. The process starts from using the researcher's knowledge in research to apply the basic research knowledge which is intangible, leading to application and then to improve and develop together with modern technology and resulting in a tangible product [18].

Research and development, therefore, play an important role in creating a competitive advantage by inventing new products and services into the market. Including innovating to develop new and different products regularly. Therefore, the development of innovation is influenced by research and development that precedes it and then develops into innovation [19].

\subsection{Perceive Value}

Customer Perceived Value (CPV) is a term originated in economics to describe the value or price of a product that increases at each stage of production or as a result of which it exceeds what is expected at the beginning. If defined according to business value-added, it means the ratio between total customer value and total customer cost. The benefits that customers receive can be classified into two types: Functional Benefit and Emotional Benefit. The cost can be divided into 4 types, which are currency costs, time costs, energy costs, and psychological costs. Therefore, organizations can add value to their customers in many ways [15].

Using value-added analytics principles, it is important to focus on measuring the value of the benefit or cost of a decision. This is because some effects cannot be quantified in a precise numerical value, such as those related to the mind, emotions, and feelings (comfort, good looks, or frustrations, etc.) which these things are of unequal importance in the feelings of each person [8].Therefore, an item can have a very high value in one's eyes but in the opinion of others, It may turn out to be a worthless or meaningless item as well. Therefore, before figuring out how to add value to any product or service, one must first find out what benefits or costs of the product or service are important in the opinion of the customer to improve it accurately. Because no matter how good the product is, but if the customer does not want it, there is no way it can be successful [10].

\subsection{Innovation and Technology}

Innovation is seen as a matter of management; therefore, entrepreneurship is the key player that plays an important role in the innovation development process. Innovation also plays a role in leading the entrepreneur to success. Furthermore, the entrepreneurial perspective assumes that those who are classified as entrepreneurs are those who can set up new businesses by combining new ideas with existing ones to create innovations to create wealth for both themselves and society [20-21]. The entrepreneur will be the center of the system that is linked between the circuits of scientific exploration, technological research, product design, and market transition. These four dimensions will lead to change and development towards innovation, creating enormous business opportunities. The main drivers that play a role in determining the benefits of those opportunities are entrepreneurs themselves. Without innovation and the drive for innovation, there is no 
innovation within the organization. Therefore, the basis of innovation is entrepreneurship [18], [22].

Innovation development is the transformation of organizational characteristics or organizational behavior, changing from the original to something that has never been modified before to be more modern and more effective to respond to the stimuli of the globalization context with knowledge and innovation as the main factors in adding value, developing, producing good quality products and services with higher efficiency and effectiveness to meet the needs and satisfaction of customers, and the survival and competitiveness of the organization in the global free trade market [23-25].

2.6 Theoretical Framework

From the concepts and literature review above, the researcher proposes components of value-added strategies for the value creation of Thai herbs in natural and herb products industry leading to patent protection are five latent variables.

In statistics, exogenous variable is brand identity (BI), and the four endogenous variables are marketing strategy (MS), research and development (RD), perceive value (PV), innovation and technology (IT).

From the ensuing discussion, the researchers propose a conceptual model presented in Figure 1, which following hypotheses are formulated:

Hypothesis 1 (H1): Brand identity has direct influence on marketing strategy.

Hypothesis 2 (H2): Brand identity has direct influence on research and development.

Hypothesis 3 (H3): Marketing strategy has direct influence on perceive value.

Hypothesis 4 (H4): Research and development has direct influence on innovation and technology.

Hypothesis 5 (H5): Perceive value has direct influence on innovation and technology. 


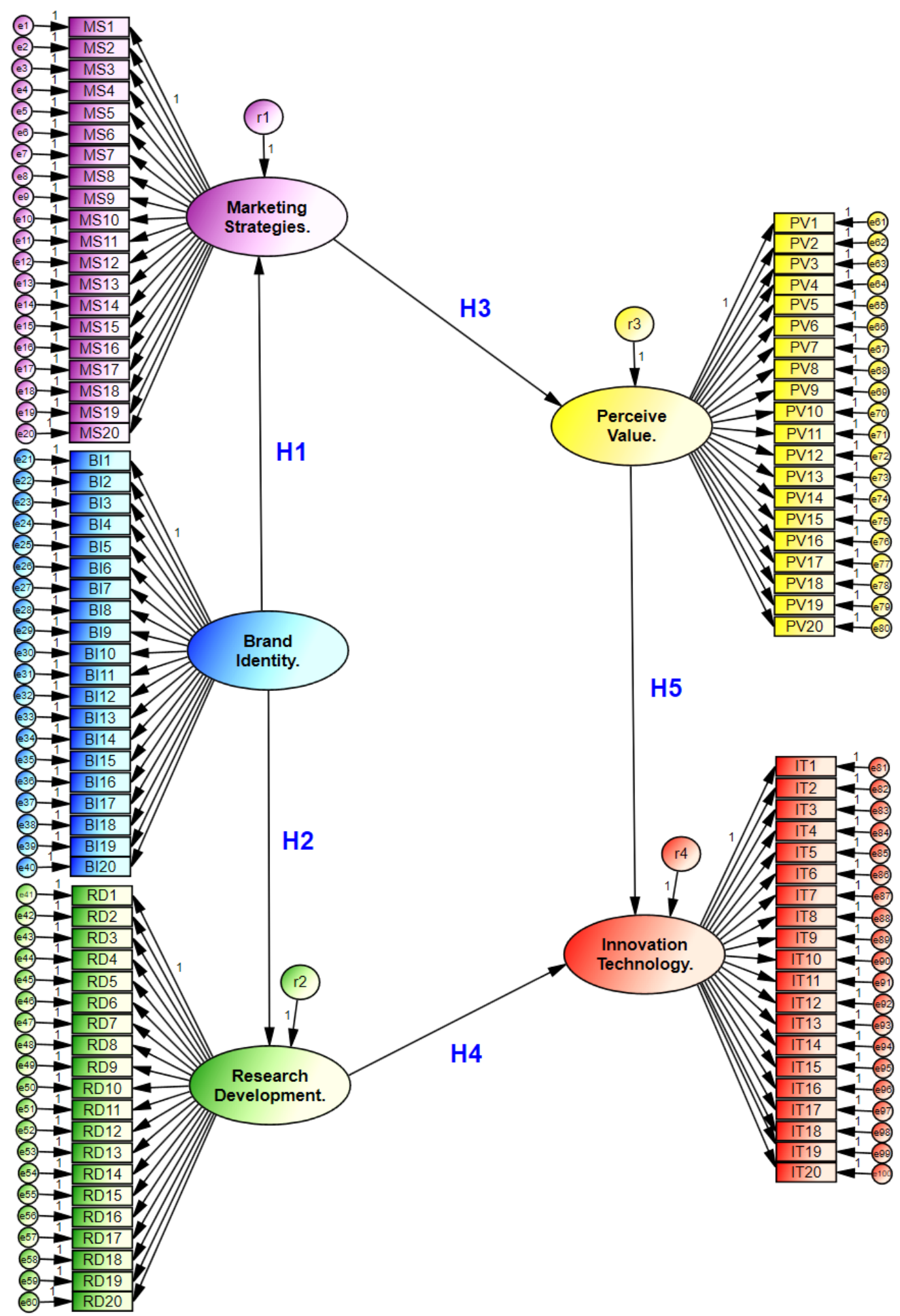

Figure 1. Conceptual framework based on structural equation modeling.

\section{Research Methods}

\subsection{Procedure Design}

This study was designed as a mixed method that comprises three parts (two parts from qualitative and one part from quantitative research). The first part, which the qualitative study, was achieved by in-depth interview technique of nine specialists who are selected under the qualification criteria of experts set according to the report 
established by Congan \& Derricott. [26]. The results of the interview from the specialists were further applied for developing the questionnaire used as a research tool to survey the opinion of entrepreneurs. In the second part, the completed questionnaire was distributed to 500 entrepreneurs in the field of natural and herbal products industry. The survey was cross-sectional descriptive research that was conducted between June 2019 and December 2019. The obtained data were analyzed by the structural equation model in order to investigate the goodness-of-fit measurement of the conceptual framework. In the final step, the qualitative focus group discussion from seven experts was applied to approve whether the factors obtain from the structural equation model was truly impact the herbal industry.

\subsection{Questionnaire Development}

The questionnaire was primarily created from the previously published works of literature and in-depth interviews. The instrument consisted of two sections: closedended question (checklist) that comprised five business characteristic information and a 5-point Likert scale [27] of 20 questions per factor total five factors [Brand Identity (BI), marketing strategies (MS), research and development (RD), innovation and technology (IT), and perceived value (PV)]. The statement in the survey asked participants to select on the level of importance that ranged from 1 (strongly unimportant) to 5 (strongly important). Before the questionnaire was sent to the participants, it was evaluated for validity and reliability. Both criteria were accepted by item objective congruence value (IOC) of 0.6 to 1.0 from 5 specialists, and Cronbach's alpha value in the range of 0.38 to 0.79 , respectively [28].

\subsection{Population and Sample}

The target population was an entrepreneur in the herbal business who had won or submitted product innovation in various public or private contests in Thailand. The names of more than 30,000 targeted companies were acquired from the database of the National Innovation Agency (Public Organization), Thailand. At the same time, 500 subjects were further randomly by multi-stage sampling from this list that met the minimum sample size required for SEM analysis according to Hair et al. recommend [29].

\subsection{Data Collection and Response Rate}

The finalized questionnaire was sent to the selected participants through email or asked them to select answers by telephone directly if not returned within the specified time or clarify possible misunderstanding and to fill in the missing data. The response rate of answering the questionnaires was $100 \%$ as shown in Table 1.

Table 1. Percentage of respondents' business characteristics.

\begin{tabular}{clcc}
\hline General business data & \multicolumn{1}{c}{ Category } & $\begin{array}{c}\text { Frequency } \\
(\mathbf{n}=\mathbf{5 0 0})\end{array}$ & Percentage \\
\hline \multirow{2}{*}{ Business size classification } & SME & 250 & 50.00 \\
& Large Enterprise & 250 & 50.00 \\
\hline \multirow{3}{*}{ Duration of operation } & $<5$ years & 252 & 50.40 \\
& $5-10$ years & 161 & 32.20 \\
& $>$ 10 years & 87 & 17.40 \\
\hline \multirow{5}{*}{ Types of Businesses } & Sole Proprietorships & 127 & 25.40 \\
& Partnerships Limited & 90 & 18.00 \\
& Community Enterprise & 112 & 22.40 \\
& Company Limited & 149 & 29.80 \\
& Public Company Limited & 22 & 4.40 \\
\hline \multirow{2}{*}{ Business Sector } & Agribusiness & 109 & 21.80 \\
& Food \& Beverage & 265 & 53.00 \\
\hline
\end{tabular}




\begin{tabular}{llcc}
\hline General business data & \multicolumn{1}{c}{ Category } & $\begin{array}{c}\text { Frequency } \\
(\mathbf{n}=\mathbf{5 0 0})\end{array}$ & Percentage \\
\hline \multirow{5}{*}{ Geographic location } & Traditional Medicine & 61 & 12.20 \\
& Services (Spa, Massage) & 38 & 7.60 \\
& Cosmetics \& Cosmeceutical & 27 & 5.40 \\
\hline & Northern & 103 & 20.60 \\
& Central & 125 & 25.00 \\
& Northeastern & 81 & 16.20 \\
& Eastern & 51 & 10.20 \\
& Southern & 58 & 11.60 \\
& Bangkok Metropolis & 82 & 16.40 \\
\hline
\end{tabular}

\subsection{Data Analysis}

The descriptive statistics method such as frequencies distribution, mean, standard deviation (S.D.), and percentage (\%) were reported, while inference statistics including Pearson's Correlation, and Cronbach's alpha analyses were performed to assess structural model validity and reliability using SPSS (Statistical Package for Social Science) version 21.0. The structural model was analyzed using AMOS (Analysis of Moment Structure) version 21.0 through which the hypotheses could be verified.

\section{Results}

\subsection{The Measurement of Model fit}

First of all, we used nine item-fit criteria together to investigate items fit simultaneously from a variety of perspectives. For structural equation models fit indices must be improved according to modification indices (MI) to eliminate some inappropriate variables one by one by considering the value of the results obtained from the program together with theoretical principles. The model was updated by employing the MI values and recalculate new processing until the model complete and consistent in harmony with empirical data. [29-30].

The goodness of fit results from the measurement model are reported in Table 2. The data indicates that the reliability and validity of the measures are as follows: relative chi-square $\left(\mathrm{CMIN} / \mathrm{DF}\right.$ or $\left.\chi^{2} / \mathrm{df}\right)=1.150$, goodness of fit index $(\mathrm{GFI})=0.963$, root mean square error of approximation $($ RMSEA $)=0.017$, root mean square residual $(R M R)=0.029$, normed fit index $(\mathrm{NFI})=0.959$, tucker lewis index $(\mathrm{TLI})=0.994$, comparative fit index $(\mathrm{CFI})$ $=0.994$, adjusted goodness of fit index $(\mathrm{AGFI})=0.953$, chi-square probability level $(\mathrm{CMIN}-\mathrm{p}$ or $p)=0.080$. The results showed a good fit, with all indices greater than the acceptable threshold.

Table 2. Goodness-of-fit (GOF) measures of structural equation model.

\begin{tabular}{ccccc}
\hline GOF Measures & $\begin{array}{c}\text { Recommended } \\
\text { Value }\end{array}$ & $\begin{array}{c}\text { Measured } \\
\text { value }\end{array}$ & Evaluation & Resource \\
\hline Absolute fit indices & & & & \\
$\chi^{2} / d f$ & $<3.000$ & 1.150 & Acceptable & {$[29]$} \\
GFI & $>0.900$ & 0.963 & Acceptable & {$[29]$} \\
$R M S E A$ & $<0.080$ & 0.017 & Acceptable & {$[29]$} \\
$R M R$ & $<0.080$ & 0.029 & Acceptable & {$[29]$} \\
Incremental fit indices & & & & \\
NFI & $>0.900$ & 0.959 & Acceptable & {$[29]$} \\
TLI & $>0.900$ & 0.994 & Acceptable & {$[29]$} \\
\hline CFI & $>0.900$ & 0.994 & Acceptable & {$[29]$} \\
Parsimony fit indices & & & & \\
$A G F I$ & $>0.900$ & 0.953 & Acceptable & {$[29]$}
\end{tabular}




\begin{tabular}{ccccc}
\hline GOF Measures & $\begin{array}{c}\text { Recommended } \\
\text { Value }\end{array}$ & $\begin{array}{c}\text { Measured } \\
\text { value }\end{array}$ & Evaluation & Resource \\
\hline$p$ & $>0.050$ & 0.080 & Acceptable & {$[29]$} \\
\hline
\end{tabular}

\subsection{The Structural Model Evaluation}

In the measurement model, convergent validity and discriminant validity were investigated after the structural model fit. In convergent validity, the outer loadings, average variance extracted (AVE) must be 0.50 or more than 0.50 and composite reliability (CR) must be 0.70 or more than 0.70 [29]. The discriminant validity was calculated by using the heterotrait-monotrait (HTMT) ratio, the criterion should be below 0.90 [31]. A Cronbach's alpha to confirm the reliability can be considered the recommended value of 0.70 or above [29].

The results were performed to examine the reliability and discriminant validity of the measures. All the observed variables were indicating how closely the selected items are related to the latent construct being assessed, the average variance extracted values of the constructs are all above the recommended level of 0.50 and all the composite reliability showing good reliability of constructs are greater than the recommended level of 0.70 to accept review quality. Cronbach's alpha was computed and represents the values of all constructs are above recommended 0.70 to ensure reliability. Convergent and discriminant validity of SEM model as can see from the data in Figure 2 and Table 3.

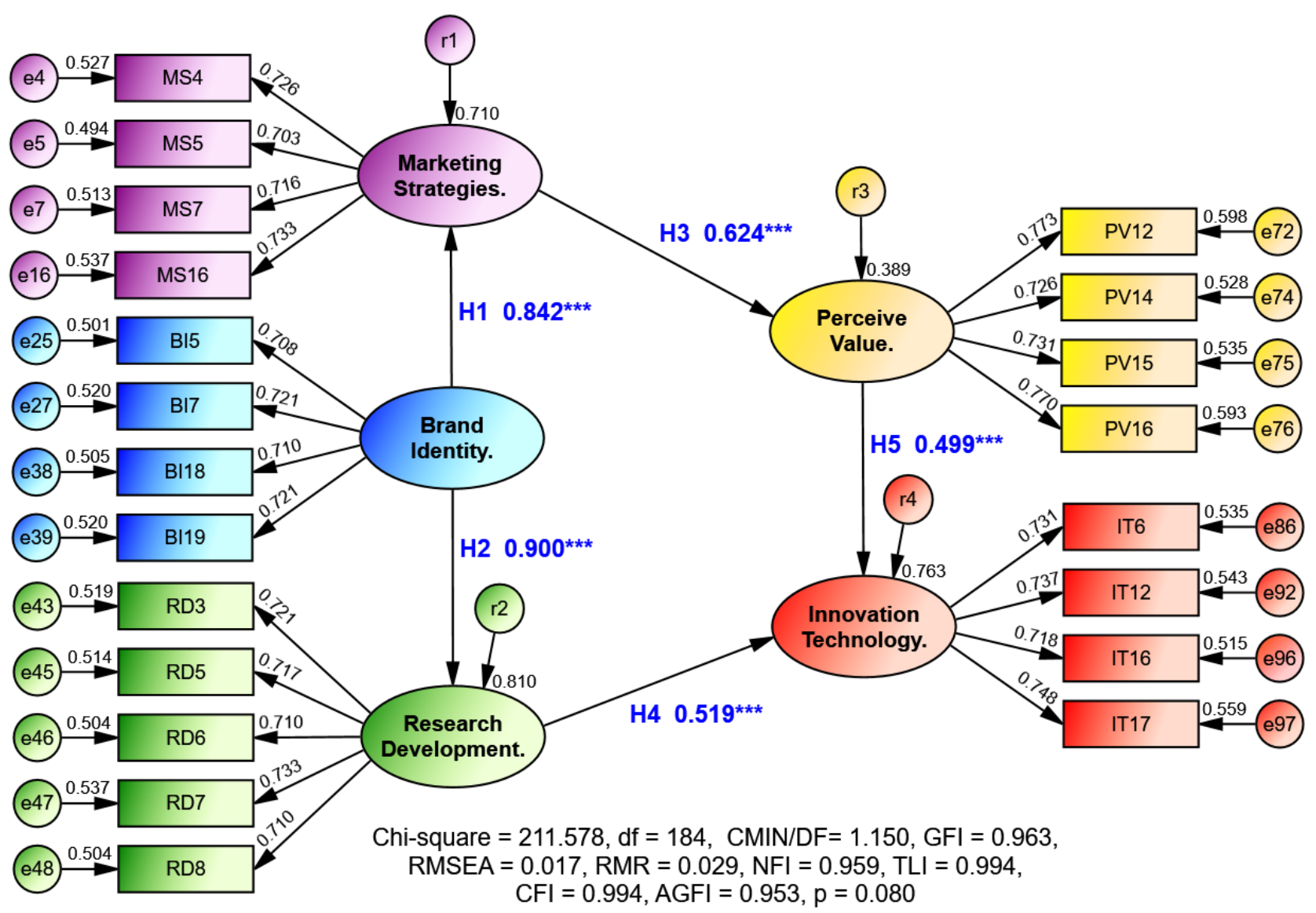

Figure 2. Result of the goodness of fit statistics in the modified model.

Table 2. This is a table. Tables should be placed in the main text near to the first time they are cited.

\begin{tabular}{ccccccc}
\hline Latent Variable & Item & Factor Loading & $\boldsymbol{R}^{\mathbf{2}}$ & CR & AVE & Cronbach's $\boldsymbol{\alpha}$ \\
\hline Marketing Strategies & MS4 & 0.726 & 0.527 & 0.811 & 0.518 & 0.807 \\
\cline { 3 - 6 }
\end{tabular}




\begin{tabular}{|c|c|c|c|c|c|c|}
\hline & MS5 & 0.703 & 0.494 & & & \\
\hline & MS7 & 0.716 & 0.513 & & & \\
\hline & MS16 & 0.733 & 0.537 & & & \\
\hline \multirow{4}{*}{ Brand Identity } & BI5 & 0.708 & 0.501 & \multirow{4}{*}{0.807} & \multirow{4}{*}{0.512} & \multirow{4}{*}{0.816} \\
\hline & BI7 & 0.721 & 0.520 & & & \\
\hline & BI18 & 0.710 & 0.505 & & & \\
\hline & BI19 & 0.721 & 0.520 & & & \\
\hline \multirow{5}{*}{ Research \& Development } & RD3 & 0.721 & 0.519 & \multirow{5}{*}{0.842} & \multirow{5}{*}{0.516} & \multirow{5}{*}{0.841} \\
\hline & RD5 & 0.717 & 0.514 & & & \\
\hline & RD6 & 0.710 & 0.504 & & & \\
\hline & RD7 & 0.733 & 0.537 & & & \\
\hline & RD8 & 0.710 & 0.504 & & & \\
\hline \multirow{4}{*}{ Perceive Value } & PV12 & 0.773 & 0.598 & \multirow{4}{*}{0.838} & \multirow{4}{*}{0.564} & \multirow{4}{*}{0.839} \\
\hline & PV14 & 0.726 & 0.528 & & & \\
\hline & PV16 & 0.731 & 0.535 & & & \\
\hline & PV17 & 0.770 & 0.593 & & & \\
\hline \multirow{4}{*}{ Innovation Technology } & IT6 & 0.731 & 0.535 & \multirow{4}{*}{0.823} & \multirow{4}{*}{0.538} & \multirow{4}{*}{0.827} \\
\hline & IT12 & 0.737 & 0.543 & & & \\
\hline & IT16 & 0.718 & 0.515 & & & \\
\hline & IT17 & 0.748 & 0.559 & & & \\
\hline
\end{tabular}

Discriminant validity was performed to examine by using the correlation analysis between each two variables as shown in Table 4. As it has been proved, the results showing good discriminant validity of the constructs, all the values below 0.90 followed by the criteria of statistically fulfilled HTMT.

Table 4. Summary of correlation analysis.

\begin{tabular}{|c|c|c|c|c|c|c|c|}
\hline Construct & Mean & S.D. & BI & MS & RD & IT & PV \\
\hline Brand Identity & 3.780 & 0.595 & 1.000 & & & & \\
\hline Marketing Strategies & 3.799 & 0.621 & $0.786^{* * *}$ & 1.000 & & & \\
\hline Research \& Development & 3.751 & 0.615 & $0.867^{* * *}$ & $0.795^{* * *}$ & 1.000 & & \\
\hline Innovation Technology & 3.707 & 0.679 & $0.696^{* * *}$ & $0.689^{* * *}$ & $0.794^{* * *}$ & 1.000 & \\
\hline Perceive Value & 3.819 & 0.635 & $0.543^{* * *}$ & $0.594^{* * *}$ & $0.587^{* * *}$ & $0.772^{* * *}$ & 1.000 \\
\hline
\end{tabular}

\subsection{The Hypothesis testing}

SEM analysis is used in this study to test the theoretical model and to confirm the factor structure of the value creation of Thai herbs. It presents the results of this study concerning the five hypotheses as shown in Table 5. As anticipated, $\mathrm{H} 1$ and $\mathrm{H} 2$ were supported, the findings revealed that BI had a positive direct impact on MS $(\beta=0.842$, $\mathrm{p}<0.001)$ and RD $(\beta=0.900, \mathrm{p}<0.001)$. Subsequently, hypothesis H3 was accepted, the results of MS had a positive and significant direct effect on PV $(\beta=0.624, \mathrm{p}<0.001)$. While hypotheses $\mathrm{H} 4$ and $\mathrm{H} 5$ were also supported, the finding of RD and PV had a statistically significant and direct influence on IT, RD $(\beta=0.624, p<0.001)$, and PV $(\beta=0.624, p<0.001)$ respectively.

Table 5. Summary of hypothesis test.

\begin{tabular}{ccccccc}
\hline Hypothesis & Path & Std. $\boldsymbol{\beta}$ & Std. Error & $\boldsymbol{t}$-Value & $\boldsymbol{p}$-Value & Results \\
\hline H1 & BI $\rightarrow$ MS & 0.842 & 0.065 & 13.211 & $0.000^{* * *}$ & Supported \\
H2 & BI $\rightarrow$ RD & 0.900 & 0.066 & 13.804 & $0.000^{* * *}$ & Supported
\end{tabular}




\begin{tabular}{lllllll} 
H3 & MS $\rightarrow$ PV & 0.624 & 0.056 & 10.393 & $0.000^{* * *}$ & Supported \\
H4 & RD $\rightarrow$ IT & 0.519 & 0.048 & 10.037 & $0.000^{* * *}$ & Supported \\
H5 & PV $\rightarrow$ IT & 0.499 & 0.048 & 9.892 & $0.000^{* * *}$ & Supported \\
\hline
\end{tabular}

Note: ${ }^{* *} \mathrm{p}<0.001$.

4.4 Definition of Variable

Brand Identity

BI5 Design products with traditional local identities.

BI7 Create a unique brand and a memorable brand identity.

BI18 Production with difficult-to-imitate technological.

BI19 Organizational change always to modern brand image

Marketing Strategies

MS4 Create a multi-channel service to help customers quickly and easily access.

MS5 Use a customer relationship management (CRM) database for customer need analysis.

MS7 Design the strategy to solve social issues profitably with creating shared value (CSV).

MS16 Strategic forecasting to support decisions of total-market demand trend.

Research \& Development

RD3 Develop a unique product response to beyond customer expectations.

RD5 Develop production processes to difficulty imitating.

RD6 Build a strong network to share knowledge exchange in an R\&D partner.

RD7 Seeking government grants to support product development.

RD8 Develop a product with different qualities as a superior competitor.

Innovation Technology

IT6 Build an effective innovation team.

IT12 Use advanced technologies and high-tech machines for manufacturing.

IT16 Allocate funds from the technology budget to cover innovation costs.

IT17 Creativity contests to inspire innovation.

Perceive Value

PV12 Create a content marketing influence on social media platforms.

PV14 Increase brand awareness through influencer marketing.

PV15 Create a social network to communicate information and build customers.

PV16 Establish a reputation with international award products.

\section{Discussion}

The Brand Identity component directly influences the Marketing Strategies component as the brand identity helps build a relationship between the brand and its target consumers by offering brand value to consumers in areas such as Functional Benefits, Emotional Benefits, and the benefits of the brand as an indicator of certain consumer status. (Self- 
expressive Benefits) [8],[10]. Therefore, to obtain such benefits Research and development are needed to produce products that meet customer needs. [32-34].

The Brand Identity component directly influences the Research \& Development component because identity is one of the key business resources that differentiate products and services. Even if building a brand's identity takes a lot of budget. As a result of such investments, product loyalty will be gained. [12], [35]. Creating a brand identity requires product research and development to make it different, stand out, and be memorable to consumers. Research \& Development plays an important role in creating a competitive advantage by inventing new products and services into the market as well as innovating to develop those products to be new and different all the time [19], [36-39].

The Marketing Strategies component directly influences the Perceive Value component as today's marketing has changed rapidly according to consumer behavior. In the era of digital marketing, content must be displayed to tell the story, myth, or the origin of the product through social media rather than focusing on advertising through radio and television like in the past [15], [40-41]. Therefore, Thai herbal business entrepreneurs turn to create product content through social media to create awareness of the value of the product from the accurate information about the safety of the use of the product as well as the properties of herbs that are important for various bioactive substances because it is a low-cost communication and can reach consumers quickly and spread widely (viral marketing) [42-43].

The research and development component directly influences Innovation Technology because research and development is the starting point for innovation and technology. The same area of research report found that Research and development influence innovation and technology [44]. Research and development are derived from strategic knowledge management and customer management knowledge. Also, the ability to integrate research and development knowledge influences product innovation and process innovation [45]

Perceive Value component directly influences Innovation Technology because creating added value in business, creating brand awareness of the organization is a stepping stone to the sustainable competitiveness of business. The value of business products requires innovation to help develop products to outperform competitors to prevent market competitors to develop their products to compete with our products [10], [46] and if the corporate product is innovative, it will be difficult for other competitors to copy it. Innovation plays a role in enabling successful entrepreneurship and enabling organizations to generate profits and grow sustainably [18]. Therefore, in addition to the organization having innovative products, it is also necessary to create awareness of the value of the product for consumers to always believe in our products [47-48].

\section{Conclusions}

Creating added value in the natural and herbal products business, entrepreneurs need to apply science and technology to research and development to obtain valuable products which are different from what is available in the market. When research and development are used to create added value, it is also necessary to develop innovative products because innovation will make it difficult to replicate. This benefit is to be used as a tool for patenting trade to protect the intellectual property of the organization. In addition, the acquired trade patent will be a marketing strategy that will be used to create brand awareness of the product, giving consumers confidence and trust in the products and services of the organization, enabling the organization to grow sustainably.

Author Contributions: Conceptualization, K.Y. and P.P.; methodology, K.Y. and T.S.; software, K.Y. and T.S.; validation, K.Y. and P.P.; formal analysis, K.Y. and T.S.; investigation, K.Y.; resources, K.Y.; data curation, K.Y.; writing-original draft preparation, K.Y.; writing-review and editing, P.P.; visualization, K.Y.; supervision, P.P.; project administration, K.Y.; funding acquisition, K.Y.

Funding: This research received no external funding.

Data Availability Statement: Not applicable. 
Acknowledgments: We wish to thank specialists who helped to oversee important components of our project and the experts who gave their time to take part in the research.

Conflicts of Interest: The authors declare no conflict of interest.

\section{References}

1. Tilburt, C.J.; Kaptchuk, J.T. Herbal medicine research and global health: an ethical analysis. Bulletin of the World Health Organization 2008, 86(8), 577-656.

2. Nirali, J.; Shankar, M.B. Global market analysis of herbal drug formulations. International Journal of Ayurveda and Pharmaceutical Chemistry 2015, 4(1), 59-65.

3. World Health Organization. WHO traditional medicine strategy: 2014-2023; WHO Press: Geneva, Switzerland, 2013 ; pp. 25-40.

4. Benzie, I.F.F.; Wachtel-Galor, S. Herbal medicine: Biomolecular and clinical aspects, 2nd ed.; CRC Press, London, United Kingdom, 2011; pp. 1-10.

5. Ministry of Commerce. Online foreign trade statistics of Thailand 2019; Information Technology and Communication Center: Bangkok, Thailand, 2019; pp. 63-71.

6. Mukherjee, K.P. Evidence-based validation of herbal medicine, Elsevier Inc.: Amsterdam, Netherlands, 2015; pp. 29-30.

7. Lall, N. Medicinal plants for holistic health and well-being, Elsevier Inc.: London, United Kingdom, 2018; pp. 1-5.

8. Salinas, G. The international brand valuation manual: A complete overview and analysis of brand valuation techniques, methodologies and applications, John Wiley \& Sons Ltd.: West Sussex, England, 2009; pp. 8-12.

9. Grant, J. The Brand innovation manifesto: How to build brands, redefine markets and defy conventions, John Wiley \& Sons Ltd.: West Sussex, England, 2006; pp. 27-29.

10. Doyle, P. Value-based marketing: Marketing strategies for corporate growth and shareholder value, John Wiley \& Sons Ltd.: West Sussex, England, 2008; pp. 227-242.

11. Ammerman, W. The invisible brand: Marketing in the age of automation, big data, and machine learning, McGraw-Hill Education: New York, United States, 2019; pp. 12-13.

12. Fisher-Buttinger, C.; Vallaster, C. Connective branding : building brand equity in a demanding world, John Wiley \& Sons Ltd.: West Sussex, England, 2008; pp. 121-123.

13. Palmatier, W.R.; Sridhar, S. Marketing strategy: Based on first principles and data analytics, Macmillan Publishers Limited: London, England, 2017; pp. 269.

14. Hooley, G.; Piercy, N.; Nicoulaud, B.; Rudd, M. J. Marketing strategy E competitive positioning. 6th ed.; Pearson Education Limited, United Kingdom, 2017; pp. 30-33.

15. Kotler, P.; Armstrong, G. Principals of marketing. 14th ed.; Pearson Prentice Hall: New York, United States of America, 2012; pp. 48-50.

16. Keller, K.L. Strategic brand management: Building, measuring, and managing brand, 4th ed.; Pearson Education: New York, United States, 2013; pp. 15-16.

17. Mikulskiene, B. Research and development project management: Study book, Mykolo Romerio universitetas: Vilnius, Lietuva, 2014; pp. $10-11$.

18. Trott, P. Innovation management and new product development, 6th ed.; Pearson Education Limited: Essex, England, $2017 ;$ pp. 274.

19. Jain, R. K.; Triandis, C.H.; Weick, W.C. Managing research, development and innovation: Managing the unmanageable, 3rd ed.; John Wiley \& Sons Ltd.: New Jersey, United States of America, 2010; pp. 5-8.

20. Betz, T. Managing Technological innovation: Competitive advantage, 3rd ed.; John Wiley \& Sons Ltd.: New Jersey, United States of America, 2011; pp. 74-76.

21. David, R.Fred; David, R. Forest; David, E.M. Strategic management: A competitive advantage approach, concepts and cases, 17th ed.; Pearson Education, Inc.: New Jersey, United States of America, 2020; pp. 115-117.

22. Ruiz-Jimenez, M.J.; Fuentes-Fuentes, M.M. Knowledge combination, innovation, organizational performance in technology firms. Industrial Management $\mathcal{E}$ Data Systems, 2013, 113(4), 523 - 540.

23. Harris, L.V.A. Idea engineering: Creative thinking and innovation, Momentum press: New York, United States of America, 2014; pp. 35-42.

24. Satell, G. Mapping innovation: A playbook for navigating a disruptive age, McGraw-Hill Education: New York, United States of America, 2017; pp. 44-58.

25. Lee, I. E-Business innovation and process management, Idea Group Inc.: London, United Kingdom, 2007; pp. $283-285$.

26. Cogan, J.J.; Derricott, R. Citizenship for the 21st Century: An international perspective on education. 2nd ed.; Stylus Publishing: Virginia, United States of America, 2001; pp. 25-30.

27. Likert, R. A Technique for the Measurement of Attitudes. Archives of Psychology, 1932, 140, 1-55.

28. Silpcharu, T. Statistical data analysis and research by SPSS and AMOS, 15th ed.; Business R\&D Ordinary Partnership: Bangkok, Thailand, 2017; pp. 94-96.

29. Hair, J.F., Jr.; Black, W.C.; Babin, B.J.; Anderson, R.E. Multivariate data analysis, 7th ed.; Pearson Education, New York, United States of America, 2010; pp. 703-742.

30. $\quad$ Arbuckle, J.L. IBM ${ }^{\circledR}$ SPSS ${ }^{\circledR}$ Amos ${ }^{T M} 20$ User's guide; IBM: New York, United States of America, $2011 ;$ pp. $597-617$. 
31. Henseler, J.; Ringle, C.M.; Sarstedt, M. A new criterion for assessing discriminant validity in variance-based structural equation modeling. Journal of the Academy of Marketing Science 2015, 43(1), 115-135.

32. Eldegwy, A.; Elsharnouby, T.H,; Kortam, W. How sociable is your university brand? An empirical investigation of university social augmenters' brand equity. International Journal of Educational Management 2018, 32(5), 912-930.

33. Rather, R.A.; Tehseen, S.; Parrey, S.H. Promoting customer brand engagement and brand loyalty through customer brand identification and value congruity. Spanish Journal of Marketing 2018, 22(3), 321-339.

34. Pérez, A.; Rodríguez del Bosque, I. How customers construct corporate social responsibility images: Testing the moderating role of demographic characteristics. Business Research Quarterly 2015, 18, 127-141.

35. Wong, R.; Tong, C.; Wong, A. Examine the Effects of customer satisfaction on customer loyalty: An empirical study in the healthcare insurance industry in Hong Kong. British Journal of Economics, Management \& Trade 2014, 4(3), 372-399.

36. Zacca, R.; Dayan, M.; Ahrens, T. Impact of network capability on small business performance. Management Decision 2014, 53(1), 2-23.

37. Wang, Edward S. T. The influence of visual packaging design on perceived food product quality, value, and brand preference. International journal of retail $\mathcal{E}$ distribution management 2013, 41(10), 805-816.

38. Lin , C. Perceived convenience retailer innovativeness: how does it affect consumers? Management Decision 2016, 54(4), 946-964.

39. Yeh, Y. Market orientation and service innovation on customer perceived value. Management Research Review 2016, $39(4)$, 44 467.

40. Kassim, N.M.; Ramayah, T.; Kurnia, S. Antecedents and outcomes of human resource information system (HRIS) use. International Journal of Productivity and Performance Management 2012, 61(6), 603-623.

41. Jiewanto, A.; Laurens, C.; Nelloh, L. Influence of service quality, university image, and student satisfaction toward WOM intention: A case study on universitas Pelita Harapan Surabaya. Procedia-Social and Behavioral Sciences 2012, 40, 16-23.

42. Singh, A.K. Modeling passengers' future behavioral intentions in airline industry using SEM. Journal of Advances in Management Research 2015, 12(2), 107-127.

43. Ju, I.; Kim, J.; Chang, M.J.; Bluck, S. Nostalgic marketing, perceived self-continuity, and consumer decisions. Management decision 2016, 54(8), 2063-2083.

44. Cui, A.; Wu, F. Utilizing customer knowledge in innovation: antecedents and impact of customer involvement on new product performance. Journal of the Academy of Marketing Science 2015, 44(4), 1-54.

45. Ruiz-Jimenez, M.J.; Fuentes-Fuentes, M.M. Knowledge combination, innovation, organizational performance in technology firms. Industrial Management \& Data Systems 2013, 113(4), 523-540.

46. Permatasari A.; Dhewanto, W. Business Model Innovation towards competitive advantage: Case study in Indonesian cosmetics and herbal health companies. Information Management and Business Review 2013, 5(8), 385-393.

47. Ferraresi, A.A.; Quandt, C.O.; Santos, S.A.; Frega, J.R. Knowledge Management, innovativeness and strategic orientation asdrivers of business performance: A survey of Brazilian companies. Journal of Knowledge Management 2012, 16(5), 688-701.

48. Mahmoud, M.A.; Hinson, R.E.; Anim, P.A. Service innovation and customer satisfaction: The role of customer value creation. European Journal of Innovation Management 2017, 21(3), 402-422. 